\title{
Tirajı En Yüksek Dört Ulusal Gazetede Yașlılık ve Sağlık/Hastalık Konulu Yazıların Değerlendirilmesi
}

\author{
Assessment of Aging, Health/Illness Related Writings in Four Most Read National Newspapers
}

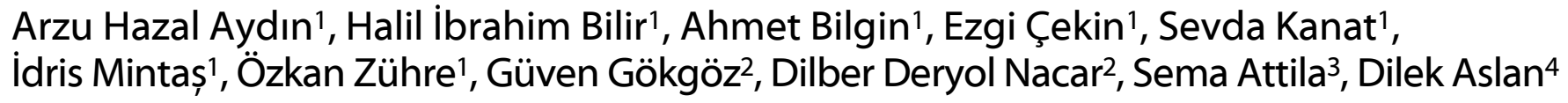

Hacettepe Universitesi Tıp Fakültesi Halk Sağılğı Anabilim Dalı Int. Dr. Hacettepe Üniversitesi Tıp Fakültesi Halk Sağlı̆ı̆ Anabilim Dalı Arş. Gör.Dr. Hacettepe Universitesi Tip Fakültesi Halk Sağlı̈̆ınabilim Dalı̈̈̆gr. Gör. Dr.

Amaç: Bu araștırmada 1 Temmuz 2015 itibarıyla tirajı en yüksek dört ulusal gazetenin 1 Ocak 2015 ile $30 \mathrm{Ha}$ ziran 2015 tarihleri arasındaki sayılarının taranmasıyla, yașlı sağlık/hastalık konulu yazıların yașlı sağlığı ve hastalıklarının ifade edilmesi açısından değerlendirilmesi amaçlanmıștır.

Gereç ve Yöntem: Milli Kütüphane Süreli Yayınlar Arșivi'nde yapılan bu araștırma tanımlayıcı tiptedir. Gazetelerde 382 yazıya ulașılmıștır. Veriler, veri toplama formu aracılığıyla toplanmıș, veri giriși ve analizler için SPSS istatistik paket programı kullanılmıștır.

Bulgular: Yayımlanan yazıların \%69,6'sının güncel durum/bilgilendirme türünde olduğu; \%73,3'ünün ana gazetede olduğu; \%93,5'inin resim/grafik içerdiği ve bunların \%97,7'sinin renkli olduğu; \%77,5'inde reklam unsuruna rastlanmadığı; \%52,6'sında kaynak belirtilmediği; \%67,3'ünde yer alan kișilerin Dünya Sağlık Örgütü'nün 65 yaș üzeri yașlı tanımına uygun olduğu; yazıların içeriklerinin \%24,9'unun yașlı sağlığıyla ilgili konulardan, \%20,8'inin psikososyal problemlerden, \%17,7'sinin ölüm haberlerinden oluștuğu; yașlı sağlık problemlerini konusundaki yazıların \%33,3'ünün nörolojik hastalıklar, \%22,2'sinin kardiyovasküler hastalıklar, $\% 11,1$ 'inin ise kanserle ilgili olduğu; yazıların \%61,2'sinin sağlığı geliștirme politikalarıyla ilgisi olmadığı; $\% 26,2$ 'sinin sağlığı geliștirme politikalarıyla uyumlu olduğu saptanmıștır.

Sonuç: Bu araștırma sonucunda yașılarla ilgili yayımlanan yazıların yarıdan fazlası güncel durum/bilgilendirme türündeyken köșe yazısı ve makale türlerinin toplamda $\% 20$ 'den az olması; medyada yașlı sağlığı ve hastalıkları hakkında halkın bilinçlendirilmesi açısından bu yazı türlerine daha çok yer verilmesi gerektiğini düșündürmektedir. Yazıların büyük çoğunluğunun resim-grafik içermesinin ve bunların tama yakınının renkli olmasının, bu haberlere ilgiyi arttırabileceği için olumlu olduğu sonucuna varılmıștır.

Anahtar Sözcükler: Yaşlı, Yaşlanma, Sağlık, Medya, Gazete

Aim: In this study, four most frequently read national newspapers as of July 1, 2015 were assessed to express elderly health and illnesses in writings (ok) which explore the concepts of agedness and health/illness by scanning the issues from 1 January to 30 June 2015.

Materials and Method: This research is descriptive type made in National Library Periodicals Archive. 382 writings were reached in newspapers. Data were collected via forms, SPSS statistical software was used for data entry and analysis.

Results: It was determined that $69.6 \%$ of the writings were informative type; $73.3 \%$ were in the main newspaper; $93.5 \%$ included pictures-graphics and $97.7 \%$ of these were colored; $77.5 \%$ had no element of advertising; $52.6 \%$ had no reference; people placed in $67.3 \%$ of the writings were in accordance with the World Health Organization's "elderly" definition (over 65 years); $24.9 \%$ of contents of the writings were about elderly health; $20.8 \%$ of them were about the psycho-social problems; $17.7 \%$ were about death news; $33.3 \%$ those mentioned health problems of the elderly were about neurological diseases, $22.2 \%$ were about cardiovascular diseases, and $11.1 \%$ were about cancer; $61.3 \%$ of the total news were not related to health promotion policies; $26.2 \%$ of them were found as in accordance with health promotion policies.

Conclusion: More than half of the elderly-related writings were informative type, columns and articles were less than $20 \%$ totally. Therefore media should give more space to these types to increase public awareness about elderly health and diseases. It was concluded as positive that majority of the writings had colored picture-graphic, thus it may increase the interest in such news.

Key Words: Aged, Aging, Health,Media, Newspaper

Yaşlanma kaçınılmaz bir süreç olup bu dönemde çevresel, genetik pek çok faktör devreye girer (1). Döneme dair birey ve toplumsal düzlemde algisal değişkenlik de söz konusudur (2). Bununla birlikte özellikle hizmetlerin planlanması, gereksinimlerin yaşa özel saptanması için kronolojik bir tanıma da ihtiyaç duyulmaktadır (3). Dünya Sağlık Örgütü (DSÖ) 65 yaş ve üzerini yaşlı olarak tanımlamıştır. Gerontoloji bilimine göre ise 65-74 yaş arası genç

Tel: +90 (312) 305 . 150 nen

Fax: +90 (312) 3110072

Hacettepe Üniversitesi Tıp Fakültesi Halk Sağlığı Anabilim Dalı Sihhiye, Ankara, 06100

Geliș Tarihi : 08.07.2016• Kabul Tarihi: 23.10.2016

iletişim

Dr. Güven GÖKGÖZ 
yaşlılık, 75-84 yaş arası orta yaşlılık ve 85 yaş üzerini ileri yaşlılık olarak tanımlamaktadır $(4,5)$.

Doğurganlığın azalması ve yaşam beklentisinin artması yaşlı nüfusun toplam nüfus içindeki payının artmasına neden olmuştur. Dünya Sağlık Örgütü raporlarına göre, 2000 yılında 600 milyon olan 60 yaş ve üstü kişi sayısının, 2025 'te 1,2 milyara, 2050'de ise 2 milyara çıkacağı tahmin edilmektedir. 2015 'te dünya nüfusunun \%12'si 60 yaş ve üzeridir (901.000.000). 60 yaş ve üzeri en yüksek olduğu yer Avrupa'dır (\%24) (6). Düşük ve orta gelirli ülkelerin yüksek gelirli ülkelere göre daha hızlı demografik değişime uğramaları beklenmektedir. Türkiye, Dünya Bankası verilerine göre orta gelirli ülke s1nıfina girmektedir (7).

Yaşlanma ile birlikte özellikle fiziksel kapasite değişimleri/gerilemeleri ve hareketlerde yavaşlama beklenir. Bununla beraber, yaşllılk döneminde bireyler yaşamlarının en birikimli dönemlerini deneyimlerler. Bu dönemde bilgelik ve içgörü üst düzeydedir (8). Yaşlanma ve ilgili süreçlere dair toplumdan topluma değişen bir yön de bulunmaktadır. Bu değişimler gündelik yaşamın içinde rahatlıkla fark edilebilir. Bununla beraber, "Etkileşim, toplumsal dinamiklerin topluma yansıtılmasında/iletilmesinde güçlü bir araç olan yazılı ve görsel medya organlarında da görülebilmektedir." (9) tanımı itibarı ile özdemir ve ark (10). "Medya, kitle iletişim araçları, yazıll, sesli, ya da görsel eserlerin dağıtımını, yayımını ya da iletimini sağlayan her türlü teknik ya da her türlü mesajin az ya da çok, geniş ya da ayrışık bir topluluk içinde yayılmasını sağlayan yöntemlerin tümüdür.” şeklinde tanımlanır.

Son yıllarda hastalık ve sağlık kavramları medyada artan bir ivmeyle görünürlük kazanmaktadır. Haber bültenlerinin mevzuatın da beklediği standart sağlık gündemlerinin yanı sıra, televizyonlarda yayımlanan programlar içerisinde reklam, bilgilendirme, vb. geniş bir yelpazede sağlık temaları dikkat çekmektedir, buna ek olarak da ayrıca sağlık programlarına yer verilmektedir (11). Bu eğilim içerisinde yaşlı sağlı̆̆1 ve hastalıkları ile ilgili yazılara dair artma beklentisi de olağandır. Yaşlıların sayıca artması, yaşlıların gereksinimlerinin farklılaşması, yaşlılık sürecinin tıbbileştirilmesi ve altta yatan bütün süreçleri, toplumda tüketim kültürünün yaygınlaşması bu beklentiyi destekleyen ve etkileşim içinde olan süreçlerdir $(11,12)$.

Türkiye'nin tirajı en yüksek gazetelerinden birinin 2008 y1lı yayımları incelendiğinde yaşlanma ve yaşlilık ile ilgili haberlerin \%3,5 sıklığında olduğu ve içeriklerin de çoğunlukla tıbbi ağırlıklı olduğu görülmüştür (11). Yaşlı sağllğ1 ve hastalıkları ile ilgili süreçlerin medyaya yansıma durumlarının izlenmesi ve medyada bu konuların nasıl ele alındığının belirli aralıklarla izlenmesi/incelenmesi konunun aksayan yönlerinin ortaya konulması açısından da değerlidir.

Yukarıdaki gerekçelere bağlı olarak bu çalişmada 1 Temmuz 2015 tarihi itibarryla tiraj1 en yüksek dört ulusal gazetenin 1 Ocak 2015 ile 30 Haziran 2015 tarihleri arasındaki sayılarının incelenmesi ile yaşlı sağlık/hastalık konularını içeren yazıların kapsamları yaşlı sağlı̆̆ ve hastalıklarının ifade edilmesi ve ortaya konulması açılarından değerlendirilmiştir. Daha ayrıntılı olarak ifade edilecek olursa, yazıların bazı özelliklerinin saptanması (haberin kapladı̆̆ yer, yayımlandığı gazete, sayfa, renkli olup olmaması, görsel içerip içermemesi, kaynak içerip içermemesi gibi), konularının belirlenmesi, yaşlılık ve sağlık/hastalık kavramlarını ele alınış biçimlerinin değerlendirilmesi, sağlığın korunmasına dair içeriğinin olup olmadığının araştırılması ve yaşlılıkla ilgili alginın olumlu ya da olumsuz yansitilma durumunun belirlenmesi amaçlanmaktadır.

\section{Gereç ve Yöntem}

Tanımlayıcı tipte yapılmış olan bu araştırma Ankara ilinde, Milli Kütüphane Süreli Yayınlar Arşivlerinde yapılmıştır. Arşivde günümüzden iki ay öncesine kadar yayınlara ulaşmak mümkündür (13).

Araştırmanın verileri 1 Temmuz 2015 tarihli en yüksek tirajlı dört gazetenin 1 Ocak 2015 ile 30 Haziran 2015 tarihleri arası arşivlerinden toplanmıştır. Gazeteciler Derneği'nin resmi web sitesinden 1 Temmuz 2015 itibarıla çıkan tiraj rapor sonucuna göre tiraj1 en yüksek dört ulusal gazete belirlenmiştir (14). Bu belirleme sonucunda Zaman, Hürriyet, Posta ve Sözcü gazeteleri incelenmiştir. İncelenen gazetelere numara verilmiş ve ilk belirlemeden sonra yapılan bütün değerlendirmeler numaralar kullanılarak yapılmıştır. Zaman (Gazete 1), Hürriyet (Gazete 2), Posta (Gazete 3) ve Sözcü (Gazete 4) olarak numaralandırılmıştır.

Yaşlilık ile ilgili haberler toplam 382'dir. Gazete 4'de 141 (\%36,9), Gazete 3'de $123(\% 32,2)$, Gazete 1'de $62(\% 16,2)$ ve Gazete 2'de $56(\% 14,7)$ haber bulunmaktadır.

Araştırmanın değişkenleri; gazetenin adı, yazının yayınlandığı tarih, yazının türü, yazının içeriği, yazının ilk yer aldığı sayfa ve ağırliklı olarak bulunduğu sayfa numarası, yazının sayfadaki yeri (alt/üst/hem alt hem üst), varsa; resim-grafik rengi (renkli/siyahbeyaz), varsa; resimde ek görseller, haber ve eğitici yazılar için yazının kaynağ1 (kaynak belirtilmiş/kaynak belirtilmemiş), yayımlanan haberde ele alınan yaş grubu, yayımlanan haberde yaşlılara yaklaşım, yayımlanan haberin yaşlı sağlığını ve yaşantısını geliştirmeye katkısı, yayımlanan haberde yaşlıların hangi sağlık problemlerinin ele alındığı, yayımlanan haberde yaşlıların yaşam alanları olarak belirlenmiştir.

Araştırma verileri 1 Ocak 2015 ile 30 Haziran 2015 tarihleri arasinda tiraji en yüksek olan dört ulusal gazetenin yaşlılı̆̆ı/yaşlı sağlı̆̆ını konu alan makale, gazete haberleri, röportaj ve köşe yazılarının incelenmesiyle toplanmıştır. Araştırmada gazetelerin Ankara Milli Kütüphane Arşivleri (MKA) kullanılmıştır (14). Veriler Ekim 2015 döneminde Halk Sağlığı staj1 yapan 7 intern doktor tarafindan toplanmıştır. Araştırmanın her aşamasında iki öğretim üyesi ve iki araştırma görevlisi akademik danışmanlık yapmışlardır. Verilerin giriși ve analizi için SPSS istatistiksel paket programı kullanılmıştır. 
Araștırmayla ilgili gazete kupürlerinin fotoğrafları çekilerek ilgili veriler veri toplama formuna kaydedilmiştir. Veri toplama formunun ön denemesi 1-2 Ekim 2015 tarihli araştırma yapılacak dört gazetenin yaşlılıkla ilgili yazıları incelenerek yapılmıstır. Her bir araştırmacı 5'er gazete yazısı değerlendirmiș ve veri toplama formunda gerekli düzeltmeler yapılmıştır.

Gazete taraması sırasında "yaş", "yaşlı", "ihtiyar", "emekli’, “düşkün”, "huzurevi”, "bakımevi", "hastane" sözcüklerini içeren yazı başlıklarının içerikleri araştırma kapsamında incelenmiştir.

Araştırmada kullanılan tanımlar ve veriler değerlendirilirken yararlanılan yaklaşımlar aşağıdaki şekildedir:

Yaşlı: Dünya Sağlık Örgütü yaşlılık dönemi için kronolojik tanımlamayı dikkate almakta ve bu dönemi " 65 yaş ve üzeri” olarak kabul etmektedir (4).

Tiraj: Bask1 say1s1 (15).

Makale: Bilim, fen konularıla siyasal, ekonomik ve toplumsal konuları açıklayıcı veya yorumlayıcı niteliği olan gazete veya dergi yazısı (15).

Köşe yazısı: Gazete veya dergilerde gündelik konuları bir görüş ve düşünceye bağlayarak yorumlayan ciddi veya eğlendirici yazı türü, fikra (15).

Röportaj: Konusu bir soruşturma, araştırma olan gazete veya dergi yazısı (15).

Yazının DSÖ'nün yaşlı tanımı ile uygunluğu: Yaşlılığın standart bir tanımı olmamakla beraber fizyolojik, biyolojik, ekonomik veya sosyolojik olmak üzere pek çok alanda tanımı bulunmaktadır. Dünya Sağlık Örgütü 65 yaş ve üstünü yaşlı olarak kabul etmiştir. 65-74 yaş arası genç yaşlılık, 75-84 yaş arası orta yaşlılık ve 85 yaş üzerini ileri yaşlılık (ihtiyarlık) devri olarak sınıflandırılmıştır $(4,5)$.

Yazının sağlığı geliştirme politikalarıyla uygunluğu, uyum durumu: Tüm dünyada yaşlı nüfus artmaktadır. Nüfusun artışına bağlı olarak da yaşlı insanların günlük yaşamlarını sürdürürken eksikliğini hissettikleri hizmetler devletler nezdinde daha bir önem kazanmakta ve politikalarını buna göre düzenlemek zorunda kalmaktadirlar. Avrupa genelinde yaşlı insanların sosyal ve ekonomik yaşamın içinde aktif bir şekilde yer almasının sağlanması yönünde birçok faaliyet düzenlenmekte, politikalar geliştirilmekte ve araştırmalar yürütülmektedir. $\mathrm{Bu}$ çalışmalarda aktif yaşlanma konusunda çeşitli kesimlere yapılan önerilere bakıldığında, ulusal ve yerel yönetimlere, ruhsal sağllk, engellilik ve kronik hastalıkların tedavisi konularına odaklanmak yoluyla koruyucu sağlık politikalarının geliştirilmesi; sağlık danışmanlığına, koruyucu hizmetlere, kaliteli sağlık hizmetlerine ve uzun dönemli bakım hizmetlerine evrensel ve eşit erişimin sağlanması; yaşlı kişilerin her türlü suiistimalinin önlenmesi; bu kişilerin bağımsız yaşamalarını teşvik edecek barınma ve ulaşım olanaklarının yaşlıların erişimlerine uygun ve güvenli hale getirilmesi ve bu kişilere evlerinde yeterli düzeyde bakım ve destek sunacak araçların sağlanması önerilmektedir. Bu öneriler de sağlığı geliştirme politikalarının temel taşlarını oluşturmaktadır (16).

\section{Bulgular}

İncelenen gazetelerde yaşlılarla ilgili haberlerde en fazla yeri \%69,6 ile $(n=266)$ güncel durum/bilgilendirme içerikli yazılar oluşturmaktadır. Yazıların \%73,3'ü $(n=280)$ ana gazetede yer almaktadır. Yazıların \%61'i $(\mathrm{n}=233)$ hafta içi gazetelerde yer almaktadır.

Yaziların \% 52,6's1 (n=201) ara sayfalarda yer almaktadir. Yazıların \%66,2'si $(\mathrm{n}=253)$ gazete sayfasinda $1 / 4$ ten daha az yer kaplamaktadır. Yayımlanan yazilarin \%42,4'ü (n=162) sayfanin üst kısmında yer almışken; \%35,9 u $(n=137)$ sayfanin alt kisimlarinda yer almaktadır.

Yaşlılarla ilgili yazıların \%93,5’ i $(n=357)$ resim veya grafik içermektedir.

Yaziların \%77,5'inde ( $\mathrm{n}=283$ ) reklam unsuruna rastlanmamıştır (Tablo 1).

Yaşlilarla ilgili yazıların \%52,6'sında ( $\mathrm{n}=201)$ kaynak belirtilmemiştir.

Tablo-1: Yazıların teknik bazı özellikleri (1 Ocak 2015-30 Haziran 2015, MKA).

\begin{tabular}{|c|c|c|}
\hline Özellik & Sayı & Yüzde \\
\hline \multicolumn{3}{|l|}{ Yayımlanan yazının türü $(n=382)$} \\
\hline Güncel durum/Bilgilendirme & 266 & 69,6 \\
\hline Köșe yazısı & 45 & 11,8 \\
\hline Röportaj & 34 & 8,9 \\
\hline Magazin & 27 & 7,1 \\
\hline Makale & 9 & 2,4 \\
\hline Biyografi & 1 & 3,0 \\
\hline \multicolumn{3}{|l|}{ Ana gazetede/ekte yer alma durumu $(n=382)$} \\
\hline Ana gazetede & 280 & 73,3 \\
\hline Ekte & 102 & 26,7 \\
\hline \multicolumn{3}{|l|}{ Hafta içi/hafta sonu yayımlanması ( $n=382)$} \\
\hline Hafta içi & 233 & 61,0 \\
\hline Hafta sonu & 149 & 39,0 \\
\hline \multicolumn{3}{|l|}{ Kaçıncı sayfada yer aldığı $(n=382)$} \\
\hline Ara sayfalar & 201 & 52,6 \\
\hline Son sayfa & 65 & 17,0 \\
\hline 3.sayfa & 35 & 9,2 \\
\hline 2.sayfa & 30 & 7,9 \\
\hline 1.sayfadan diğer sayfaya yönlendirme & 28 & 7,3 \\
\hline Sadece 1. Sayfa & 23 & 6,0 \\
\hline \multicolumn{3}{|l|}{ Sayfada kapladığı alan ( $n=382)$} \\
\hline $1 / 4^{\prime}$ ten az & 253 & 66,2 \\
\hline $1 / 4-1 / 2$ arası & 76 & 19,9 \\
\hline $1 / 2$ 'den fazla & 53 & 13,9 \\
\hline \multicolumn{3}{|l|}{ Sayfadaki yeri $(n=382)$} \\
\hline Üst & 162 & 42,4 \\
\hline Alt & 137 & 35,9 \\
\hline Hem alt hem üst & 83 & 21,7 \\
\hline \multicolumn{3}{|l|}{ Resim ya da grafik varlığı ( $n=382)$} \\
\hline Yok & 25 & 6,5 \\
\hline Var & 357 & 93,5 \\
\hline \multicolumn{3}{|l|}{ Reklam unsuru içerip içermediği $(n=365) *$} \\
\hline Hayır & 283 & 77,5 \\
\hline Evet & 82 & 22,5 \\
\hline
\end{tabular}

17 adet yazının reklam unsuru içerip içermediği net olmadığı için $n=365$ olmuştur. 
Yaziların \%67,3'ünde ( $\mathrm{n}=257)$ yer alan kişilerin DSÖ'nün 65 yaş üstü yaşlı tanımina uygun olduğu saptanmıştır. Yaş aralığ1 belirtilen 286 kişinin \%88,5’i $(n=253) 65$ yaş ve üzerindedir.

Yazıların içeriklerini \%24,9'unu ( $\mathrm{n}=97$ ) yaşlı sağlığı ile ilgili konular, \%20,8’ini $(\mathrm{n}=81)$ psiko-sosyal problemler, $\% 17,7$ 'sini $(n=69)$ ölüm haberleri oluşturmaktadır.

Yazıların \%61,2'sinin ( $\mathrm{n}=234)$ sağllğı geliştirme politikaları ile ilgisi saptanamamıstır. Yazıların \%26,2'si ( $\mathrm{n}=100)$ sağlığı geliştirme politikaları ile paralellik gösterdiği saptanmıştır (Tablo 2).

Yaşlı sağlık problemlerini konu edinen yaziların (n=108) \% 33,3’ü (n=36) nöro-

Tablo-2: Yazıların yaşıııkla ilgili olan bazı özellikleri (1 Ocak 2015 - 30 Haziran 2015, MKA).

\begin{tabular}{|c|c|c|}
\hline Özellik & Sayı & Yüzde \\
\hline \multicolumn{3}{|l|}{ Yazının kaynağı (n=382) } \\
\hline Kaynak belirtilmemiș & 201 & 52,6 \\
\hline Kaynak belirtilmiș, referans yok & 95 & 24,9 \\
\hline Kaynak belirtilmiș, referans var & 86 & 22,5 \\
\hline \multicolumn{3}{|l|}{ Yașlı tanımının DSÖ uyumu ( $n=382)$} \\
\hline Uygun & 257 & 67,3 \\
\hline Uygun değil & 29 & 7,6 \\
\hline Yaș aralığı belirtilmemiș & 96 & 25,1 \\
\hline \multicolumn{3}{|l|}{ Yaș aralığı $(\mathbf{n}=\mathbf{2 8 6})^{*}$} \\
\hline 65 ve üzeri & 253 & 88,5 \\
\hline $60-64$ & 18 & 6,3 \\
\hline $50-59$ & 14 & 4,9 \\
\hline 50 yaș altı & 1 & 0,3 \\
\hline \multicolumn{3}{|l|}{ Yazının içeriği $(n=382)^{* *}$} \\
\hline Yașlı sağlığı & 97 & 24,9 \\
\hline Psiko-sosyal problemler & 81 & 20,8 \\
\hline Ölüm haberleri & 69 & 17,7 \\
\hline Yașlı ihmal/istismarı & 35 & 8,9 \\
\hline Yașlı sağlığını geliștirmeye yönelik hizmetler & 31 & 7,9 \\
\hline Yașlı kazaları & 20 & 5,2 \\
\hline Yașlıların yașam alanları & 19 & 4,9 \\
\hline Yașlılıkla ilgili genel bilgiler & 12 & 3,2 \\
\hline Nüfus verilerinin paylașımı & 9 & 2,4 \\
\hline Ekonomik problemler & 8 & 2,1 \\
\hline Hukuki problemler & 5 & 1,2 \\
\hline Diğer**** & 3 & 0,8 \\
\hline \multicolumn{3}{|c|}{ Yazının sağlığı geliștirme politikaları ile uyumu/uygunluğu (n=382) } \\
\hline Belirtilmemiș & 234 & 61,2 \\
\hline Uygun & 100 & 26,2 \\
\hline Uygun değil & 48 & 12,6 \\
\hline
\end{tabular}

Tablo-3: Yazılarda ele alınan sağlık sorunları (1 Ocak 2015- 30 Haziran 2015,MKA)

\begin{tabular}{lll} 
Sağlık sorununun ait olduğu sistem/alan & Sayı & Yüzde* \\
\hline Nöroloji & 36 & 33,3 \\
Kardiyovasküler sistem & 24 & 22,2 \\
Kanser & 12 & 11,1 \\
Endokrin & 9 & 8,4 \\
Kas ve iskelet sistemi & 9 & 8,4 \\
Solunum & 8 & 7,4 \\
Psikiyatri & 5 & 4,6 \\
Üreme sağlığı & 5 & 4,6 \\
\hline
\end{tabular}

lojik hastalıklar, \%22,2'si ( $\mathrm{n}=24)$ kardiyovasküler sistem hastalıkları, $\% 11,1$ 'i $(n=12)$ ise kanser ile ilgilidir (Tablo 3).

Yaşlılarla ilgili yazılar en sık güncel durum/bilgilendirme şeklinde yayımlanmiştır. Güncel durum/bilgilendirmeye en fazla s1klikta Gazete 1'de $(\% 90,3)$ yer verilmiştir.

Yazıların ana gazetede bulunma yüzdesi en fazla Gazete 1'dedir $(\% 91,9)$. Gazete 4'te ana gazetede bulunma $(\% 59,6)$ ile ekte bulunma $(\% 40,4)$ yüzdeleri birbirine yakındır.

Yazılar, hafta içi en fazla Gazete 4'te (\% $66,7)$, hafta sonu ise en fazla Gazete

.

2'de $(48,2)$ yer almıştır. Yazıların içeriğindeki reklam unsuru en fazla Gazete 4 'te $(\% 35,5)$ olmuştur.

Yazılar en çok ara sayfalarda yayımlanmıştır. Gazete 2'de yazıların ara sayfalarda bulunma yüzdesi 78,6'dır.

Çoğu yazının sayfada kapladığı alanın sayfanın çeyrek alanından az olduğu saptanmıştır.

Yazıların sayfadaki yerine bakıldığı zaman yazının altta ve üstte olmasına göre en büyük fark Gazete 2'de olup $\% 42,9$ 'unda üstte $\% 12,5$ 'inde altta yer almaktadır.

Yaşlılarla ilgili yazıların çoğunda kaynak belirtilmemiş olup bu yüzde en fazla Gazete 4'tedir $(\% 63,1)$.

İncelenen yazıların çoğunda yaşlıların DSÖ'nün yaşlı tanımına uygun olduğu görülmüştür. Bununla ilintili en yüksek yüzde Gazete 3'te olmuştur $(\% 75,6)$.

Yazılarda işlenen sorunların uygulanan sağlık politikalarıyla bir ilişkisi saptanamamıștır (Tablo 4).

\section{Tartıșma}

Milli Kütüphane Arşivlerinde yapılan çalışmada, 1 Temmuz 2015 tarihi itibarıla tiraj1 en yüksek dört ulusal gazetenin 01.01.2015-30.06.2015 tarihleri arasindaki yaşlı/yaşlı sağlığı ile ilgili yazıların taranmas1 sonucunda 382 adet yazıya ulaşılmıştır. Yazıların iki gazetede (Gazete 3 ve 4) daha fazla sayida yayımlandığı saptanmıştır. Gazetelerin ekleri de değerlendirildiğinde, Gazete 4'ün sayfa sayısının diğer gazetelere göre daha fazla olduğu, Gazete 3’ün ise Cuma günleri 'yaşlılık/yaşlanma' konulu köşesinin olduğu belirlenmiştir.

Yazıların yayımlanma tarihi ve sayısının yazıya konu olan kişinin toplumda tanınma/bilinme durumu, yaşlılık ile ilgili özel günlerin varlığı gibi konulardan etkilenmiş olabileceği düşünülmektedir. Örneğin, 16-24 Mart Ulusal Yaşlilara Sayg1 haftasında yazıların \% 6,0's1 (n=23) yayımlanmıştır. Yaşlılara Sayg1 haftasinda daha fazla yazı olması beklenmektedir. Bu değerin, haftalık yaşlı ile ilgili ortalama yayım değerinin 
$(\mathrm{n}=16)$ üzerinde olması yeterli olmamakla birlikte anlamlı bir bulgudur. Milli Kütüphane Arşivlerinde yapılan bu çalışmada yazılar konuları açısından incelendiğinde yazıların \%18'inin $(n=69)$ ölüm haberi olduğu saptanmıştır. Haberlerin dağılımları incelendiğinde genellikle ünlü kişilerin ölümlerinden sonraki üç-dört gün boyunca yayımlandığı saptanmıştır. Bu haberlerin yayımlanma tarihleri incelendiğinde \%33'ünün $(n=23)$ Haziran ayında olduğu saptanmıştır. Bunun sebebinin de Haziran ayında ünlü bir siyasetçiyle ünlü bir tiyatrocunun yaşamını kaybetmiş olduğu düşünülmektedir.

Yayımlanan yazıların türleri incelendiğinde yazıların \%69,6'sının $(n=266)$ güncel durum ve bilgilendirme içerikli olduğu, köşe yazısı, röportaj, makale gibi diğer yazı türlerinin toplamının bilgilendirme içerikli yazılardan daha az olduğu saptanmıştır (Tablo 1). Yaşllık gibi toplumda farkındalık düzeyi geliştirilmeye çalışılan bir konu için bilimsel kanitlardan daha fazla yararlanilması beklenen makale, referans olan röportaj, vb. yazıların sayıca daha fazla yayımlanmış olması önemli bir beklentidir. Oysa, MKA kullanılarak yapılan bu çalışmada yazıların sadece \%22,5'inde kaynak belirtilmiş ve referans gösterilmiştir (Tablo 2).

Yaşlı/yaşlı sağlığı ile ilgili yazılarda renkli resim ve grafik kullanilması ve yazıların büyük puntolarla yazılması yazının okuyucu tarafindan daha dikkat çekici olmasını sağlayan bir faktördür (17). Milli Kütüphane Arşivlerinde yapılmış olan bu çalışmada yażların $\% 93,5$ 'inde grafik bulunmaktadır $(\mathrm{n}=357)$ (Tablo 1). Grafik bulunan haberlerin \%97,7'sinin renkli olduğu saptanmıştır. Bununla birlikte, yazılarin \%66,2'si (n=253) sayfanın dörtte birinden az yer kaplamakta, sadece $\% 6$ 's1 (n=23) ilk sayfada yer almakta, hiçbir yazıya "manşette" yer verilmemektedir. Bütün bu ayrıntıların yazılarin okuyucu tarafindan dikkatle izlenmesinin önünde bir engel olabileceği düşünülmektedir (Tablo 1).

Ülkemizde gazetelerde yer alan haberlerin incelendiği başka çalışmalar da bulunmaktadır. Örneğin; en yüksek tirajlı üç günlük gazetedeki sağlıkla ilgili haberlerin incelendiği bir çalışmada; haberlerin $\% 57$ 'sinin resimli olduğu, \%30'unun puntolu yazıldığ1 bulunmuştur (18). Bahsi geçen bulgular MKA'da yapılan bu çalışma sonuçları ile uyumludur.

Dünya Sağllk Örgütü kriterlerine göre 65 yaş ve üzeri yaşl1, 85 yaş ve üzeri ise çok yaşlı olarak tanımlanmıştır (4). Daha ayrıntılı incelendiğinde; 65-74 yaş arası genç yaşl11ık,75-84 yaş arası orta yaşlillk ve 85 yaş ve üzerini ileri yaşl11ık (ihtiyarlık) olarak tanımlanmıştır (5). Milli Kütüphane Arşivlerinde yapılan araştırmada gazetelerdeki yaşlı taniminin \%67,3 (n=257) DSÖ kriterlerine uygun olduğu, yaş aralığı belirtilen yazilarda $(n=286) \% 0,3(n=1) 50$ yaş altının, \%4,9 $(\mathrm{n}=14)$ 50-59 yaş araliğının, \%6,3 ( $\mathrm{n}=18)$ 60-64 yaş aralığının DSÖ'nün aksine yaşlı olarak tanımlandığ1 saptanmıştır (Tablo 2). Bu bilgiler 1şığında "yaşlı" kavramının topluma ulaşan bu yayımlarda yanlış kullanımının fazla olduğu, yanlış kullanımın da toplumun yanlış yönlendirilmesine neden olabileceği düşünülmektedir. Güncel veriler, her gün ortalama 4103583 gazete satıldığına işaret etmektedir (19).

Tablo 4: Yazıların bazı özelliklerinin gazetelere göre dağılımları (1 Ocak 2015-30 Haziran 2015, MKA).

\begin{tabular}{|c|c|c|c|c|c|c|c|c|}
\hline \multirow{2}{*}{ Yazıya ilișkin özellik } & \multicolumn{2}{|c|}{ Gazete 1} & \multicolumn{2}{|c|}{ Gazete 2} & \multicolumn{2}{|c|}{ Gazete 3} & \multicolumn{2}{|c|}{ Gazete 4} \\
\hline & Sayı & Yüzde & Sayı & Yüzde & Sayı & Yüzde & Sayı & Yüzde \\
\hline \multicolumn{9}{|l|}{ Türü } \\
\hline Güncel durum/bilgilendirme & 56 & 90,3 & 32 & 57,1 & 95 & 77,2 & 83 & 58,9 \\
\hline Makale & 1 & 1,6 & - & - & 1 & 0,8 & 7 & 5,0 \\
\hline Köșe yazısı & 1 & 1,6 & 16 & 28,6 & 12 & 9,8 & 16 & 11,3 \\
\hline Röportaj & 2 & 3,3 & 8 & 14,3 & 11 & 8,9 & 13 & 9,2 \\
\hline Diğer & 2 & 3,2 & - & - & 4 & 3,3 & 22 & 15,6 \\
\hline $\begin{array}{l}\text { Ana gazetede/ekte yer alma } \\
\text { durumu } \\
\text { Ana gazetede }\end{array}$ & 57 & 91,9 & 40 & 71,4 & 99 & 80,5 & 84 & 59,6 \\
\hline Ekte & 5 & 8,1 & 16 & 28,6 & 24 & 19,5 & 57 & 40,4 \\
\hline \multicolumn{9}{|l|}{$\begin{array}{l}\text { Hafta içi/sonu yayımlanma } \\
\text { durumu }\end{array}$} \\
\hline Hafta içi & 35 & 56,5 & 29 & 51,8 & 75 & 61,0 & 94 & 66,7 \\
\hline Hafta sonu & 27 & 43,5 & 27 & 48,2 & 48 & 39,0 & 47 & 33,3 \\
\hline \multicolumn{9}{|l|}{ Reklam içerip içermediği } \\
\hline İçermiyor & 56 & $\begin{array}{l}0,1 \\
90,3\end{array}$ & 54 & $\begin{array}{l}3,0 \\
96,4\end{array}$ & $\begin{array}{l}25 \\
93\end{array}$ & $\begin{array}{l}20,3 \\
75,6\end{array}$ & $\begin{array}{l}50 \\
80\end{array}$ & $\begin{array}{l}35,5 \\
56,7\end{array}$ \\
\hline Belirsiz & 1 & 1,6 & - & - & 5 & 4,1 & 11 & 7,8 \\
\hline \multicolumn{9}{|l|}{ Hangi sayfada yayımlandığı } \\
\hline Sadece 1. Sayfada & 1 & 1,6 & 1 & 1,8 & 14 & 11,4 & 7 & 5,0 \\
\hline 1.sayfadan iç sayfalara geçiș & 3 & 4,8 & 2 & 3,6 & 9 & 7,3 & 14 & 9,9 \\
\hline 2. sayfada & 8 & 12,9 & 4 & 7,1 & 3 & 2,4 & 15 & 10,6 \\
\hline 3. sayfada & 3 & 4,8 & 2 & 3,6 & 13 & 10,6 & 17 & 12,1 \\
\hline Ara sayfalarda & 32 & 51,6 & 44 & 78,6 & 70 & 56,9 & 55 & 39,0 \\
\hline Son sayfada & 15 & 24,3 & 3 & 5,4 & 14 & 11,4 & 33 & 23,4 \\
\hline \multicolumn{9}{|l|}{ Sayfada kapladığı yüzde } \\
\hline Çeyrekten az & 44 & 71,0 & 25 & 44,6 & 91 & 74,0 & 93 & 66,0 \\
\hline Çeyrek -yarım arası & 12 & 19,4 & 19 & 33,9 & 17 & 13,8 & 28 & 19,9 \\
\hline Yarıdan az & 6 & 9,6 & 12 & 21,4 & 15 & 12,2 & 20 & 14,1 \\
\hline \multicolumn{9}{|l|}{ Sayfadaki yeri } \\
\hline Alt & 29 & 46,8 & 7 & 12,5 & 42 & 34,1 & 59 & 41,8 \\
\hline Üst & 26 & 41,9 & 24 & 42,9 & 61 & 49,6 & 51 & 36,2 \\
\hline Hem alt hem üst & 7 & 11,3 & 25 & 44,6 & 20 & 16,3 & 31 & 22,0 \\
\hline \multicolumn{9}{|l|}{ Kaynağı } \\
\hline Kaynak belirtilmiș referans var & 10 & 16,1 & 3 & 5,4 & 39 & 31,7 & 34 & 24,1 \\
\hline Kaynak belirtilmiș referans yok & 22 & 35,5 & 40 & 71,4 & 15 & 12,2 & 18 & 12,8 \\
\hline Belirtilmemiș & 30 & 48,4 & 13 & 23,2 & 69 & 56,1 & 89 & 63,1 \\
\hline \multicolumn{9}{|l|}{$\begin{array}{l}\text { Yazının DSÓ tanımı ile uy- } \\
\text { gunluğu }\end{array}$} \\
\hline Evet & 41 & 66,1 & 37 & 66,1 & 93 & 75,6 & 86 & 61,0 \\
\hline Hayır & 4 & 6,5 & 2 & 3,6 & 2 & 1,6 & 21 & 14,9 \\
\hline Belirsiz & 17 & 27,4 & 17 & 30,4 & 28 & 22,8 & 34 & 24,1 \\
\hline \multicolumn{9}{|l|}{$\begin{array}{l}\text { Yazının sağlık politikaları ile } \\
\text { uyumu/uygunluğu }\end{array}$} \\
\hline Evet & 21 & 33,9 & 9 & 16,1 & 37 & 30,1 & 33 & 23,4 \\
\hline Hayır & 9 & 14,5 & 10 & 17,9 & 14 & 11,4 & 15 & 10,6 \\
\hline Belirsiz & 32 & 51,6 & 37 & 66,1 & 72 & 58,5 & 93 & 66,0 \\
\hline
\end{tabular}


Yaşlanma ile birlikte insan vücudunda çeşitli değişiklikler meydana gelmekte ve bunun sonucu olarak da hareket sistemi ile ilgili sorunlar, görme ve işitme problemleri gibi fizyolojik değişimlerin yol açtığı sorunların yanı sıra, hipertansiyon, kalp-damar sistemi hastalikları, bazı kanserler, diyabet, kronik akciğer hastalıkları gibi bazı sağlık sorunları ortaya çıkmaktadır (20). Bu sorunların medyada da yansiması beklenmektedir. Bu beklenti ile uyumlu olarak MKA'dan yararlanılarak yapılan çalışmada yaşlı hastalıkları ile ilgili yaziların (n=108) \%33,3'ü (n=36) nörolojik hastalıkları, \%22,2'si (n=24) kardiyovasküler sistem hastalıklarını, $\% 11,1$ i ise $(n=12)$ kanser olgularının konu alındığı saptanmıştır (Tablo 3).

Milli Kütüphane Arșivleri'nde yapılan bu çalışmanın sonucunda incelenen yaşlı/yaşlı sağlığı ile ilgili yazıların türleri, boyutları, içerikleri incelenmiştir. Yazı türünün genelde genel durum/bilgilendirme olduğu, yazının ara sayfalarda yer aldığı ve küçük boyutlarda yer aldığ1 görülmüsstür. Gazetelerin yaşlılık kavramı, yaşlı sağllŏ̆1, yaşlanan toplumun problemleri konularında farkındalık oluşmasına katkı sağlaması beklenmektedir. Yaşlılığı konu alan yazıların dikkat çekici olmaması, üzerinde durulması ve düzeltilmesi gereken bir konudur. Bu çalışmanın yaşlı/yaşlı sağlığı kavramları ile ilgili daha sonra yapilacak çalışmalara altyapı oluşturması ve toplumsal farkındalığa katkı sağlaması amaçlanmaktadır.

Araștırmanın bazı kısıtlılıkları bulunmaktadır. Aynı tarihteki diğer gazetelerin incelenememiş olması, yerel gazetelerin dişarıda bırakılmış olması, araştırma sırasında belirlenmiş olan dönem dışındaki verilerin dışarıda bırakılmıs olması, aynı haberin farklı gazetelerde konu edilmesi, haberin "tekrar" haber olma ihtimalinin doğurması, araştırma süresinin k1sıtlı olması, araştırmaya dahil edilecek yazıların başlıkta bazı kelimeleri içermesine göre seçilmesi sonucunda içeriğinde yaşlı/yaşlı sağlığı konusu olmasına rağmen başlığında belirtilmeyen yazıların araştırmaya dahil edilememiş olması araştırmanın öne çıkan kısıtlılıkları olmuştur.

Sonuçlardan yola çıkarak yazıların daha ön sayfalarda yer almasının sağlanması, yazıların daha çok dikkat çekebilecek, daha büyük yer kaplayan yazılar şeklinde yayımlanması, yayımlanan makale sayısının arttırılması, yaşlılık/yaşlı sağlığ1 konulu sürekli, özel gazete alanlarının arttırılması, yazıların kaynak gösterilerek ya da uzman kişi referanslarına dayalı olarak yayımlanması, konuya dair farkındalığın geliştirilmesi için yaşlılık/yaşlı sağlığını konu alan 1 Ekim ya da 16-24 Mart gibi özel gün ve dönemlerde yayımlanacak yazıların sayısının artırılması, sağlığı geliştirme politikalarıyla uyumlu yaziların arttırılması, diğer basım ve yayım organları üzerinden de benzer tanımlayıcı nitelikli çalışmalar yapılarak konu ile ilgili daha geniş çaplı durum tespitinin yapılabilmesi öneriler arasındadır.

\section{KAYNAKLAR}

1. Özgül A. Geriatrik Patolojinin Esasları (Kutsal YG, Beyzova M, Editörler). Fiziksel Tip ve Rehabilitasyon. Ankara, Güneş Kitapevi; 2000, pp 1341-1352.

2. Caniklioğlu N. Yaşlılık Sigortasının Yeniden Yapılandırılmasının Esasları, Sosyal Güvenliğin Yeniden Yapılandırılması Semineri; 7-8 Aralık 2006, TISK Yayınları, Ankara, 2007, pp 191-226.

3. Rose MR, Mueller LD. Evolution of human lifespan: past future and present. Am J Hum Biol 1998;10:409-420.

4. Beğer T, Yavuzer H. Yaşlılık ve yaşlılık epidemiyolojisi. Klinik Gelişim (Geriatri Özel Sayıs1) 2012;3: 1-3.

5. [Internet] http://www.who.int/ageing/global-strategy/GSAP-ageing-healthdraft.pdf?ua=1. Erişim: 29.09.2015.

6. [Internet] http://esa.un.org/unpd/wpp/ Publications/Files/Key_Findings_WPP_ 2015.pdf. Erişim:29.09.2015.

7. Hochschild AR. Disengagement theory: a critique and proposal. Am Sociol Rev 1975;40: 553-569.

8. Sezgin D. Yaşam Tarzı Önerileri Bağlamında Sağlik Haberlerinin Analizi. Ankara Üniversitesi Sosyal Bilimler Enstitüsü Dergisi 2011;2: 52-53.

9. [Internet] http://www.mkutup.gov.tr/tr/ Sayfalar/Kutuphane-Kullanimi/Kutuphanemizi-Taniyalim.aspx Milli Kütüphane Tanıtım Broşürü. Erişim:30.09.2015.

10. [Internet] http://www.gazeteciler.com/gazete-tirajlari.html Erişim:30.09.2015.

11. [Internet] http://tdk.gov.tr/ Erişim:01.11. 2015.

12. Türkiye Cumhuriyeti Avrupa Birliği Bakanlı̆̆ı. Avrupa Aktif Yaşlanma ve Nesiller Arası Dayanışma Yılı Hakkında Bilgi Notu. Ankara; 2011. [Internet] http://www.abgs.gov. tr/files/SBYPB/Sosyal\%20Politika\%20ve\%20
$\%$ C4\%B0stihdam/aktif_yaslanma_bilgi_ notu.pdf Erişim: 01.10.2015.

13. Uzoğlu Bayçu S, Elden M, Başokyurdakul N ve ark. Halkla İlişkiler Yazarlığı. TC Anadolu Üniversitesi Yayını No: 2765 Açıköğretim Fakültesi Yayını No: 1723. [Internet] http://docplayer.biz.tr/3620403-Halkla-iliskiler-yazarligi.html. Erişim:18.10.2015.

14. Pehlivan E, Genç M, Karaoğlu L. Üç Büyük Tirajlı Büyük Gazetelerdeki Sağlıkla İlgili Haberlerin İncelenmesi. Turgut Özel Tip Merkezi Dergisi 1994;1(2):132-140. [Internet] http://www.totmdergisi.org/articles/1994/ volume1/issue2/1994_1_2_11.pdf. Erişim: 18.10.2015.

15. [Internet] http://www.gazeteciler.com/gazete-tirajlari.html Erişim:15.10.2015.

16. [Internet] http://www.geriatri.org.tr/pdfler/Yaslanan'Toplum.pdf Erişim:10.10.2015 